\title{
Correction to: Development and evaluation of an individual tree growth and yield model for the mixed species forest of the Adirondacks region of New York, USA
}

Aaron Weiskittel ${ }^{1}$, Christian Kuehne ${ }^{1,4^{*}}$, John Paul McTague ${ }^{2}$ and Mike Oppenheimer ${ }^{3}$

\section{Correction to: Weiskittel et al. Forest Ecosystem https://doi.org/10.1186/s40663-016-0086-3}

In the publication of this article (Weiskittel et al., 2016), there are errors. The corrections have now been included in this correction.

Equation 2 The term 'CSI' should be changed to 'In(CSI)'.

The correct equation should read as follows:

$$
\mathrm{BGT}=\frac{\mathrm{HT}}{\left(1+\exp \left(b_{20}+b_{21} \mathrm{HT}+b_{22} \ln (\mathrm{BAL}+0.1)+b_{23} \ln (\mathrm{BA})+b_{24} \cdot \ln \left(\frac{\mathrm{DBH}}{\mathrm{HT}}\right)+b_{25} \cdot \ln (\mathrm{CSI})\right)\right)}
$$

Equation 3 The term 'CSI' should be changed to ' $\ln (\mathrm{CSI})$ '. The correct equation should read as follows:

$$
\begin{aligned}
\Delta \mathrm{DBH}= & \exp \left(b_{30}+b_{31} \ln (\mathrm{DBH})+b_{32} \mathrm{DBH}\right. \\
& \left.+b_{33}(\mathrm{BAL})+b_{34} \sqrt{\mathrm{BA}} b_{35}+\ln (\mathrm{CSI})\right)
\end{aligned}
$$

Equation 4 The term '(DBH/HT)' should be changed to '(HT/DBH)'. The correct equation should read as follows:

$$
\begin{array}{r}
\Delta \mathrm{HT}=\exp \left(b_{40}+b_{41} \mathrm{HT}+b_{42} \ln (\mathrm{HT})+\left(\frac{\mathrm{HT}}{\mathrm{DBH}}\right)\right. \\
\left.+b_{44}(\mathrm{BAL})+b_{45} \mathrm{BA}+b_{46} \ln (\mathrm{BA})\right)
\end{array}
$$

\section{Author details}

${ }^{1}$ University of Maine, School of Forest Resources, Orono, ME 04469, USA. ${ }^{2}$ Rayonier, Forest Research Center, Yulee, FL 32041, USA. ${ }^{3}$ Rayonier Forest Resources, Fernandina Beach, FL 32035, USA. ${ }^{4}$ University of Maine, 5755 Nutting Hall, Orono, ME 04469-5755, USA.

Received: 27 December 2018 Accepted: 3 April 2019

Published online: 26 April 2019

\section{Reference}

Weiskittel A, Kuehne C, McTague JP et al (2016) Development and evaluation of an individual tree growth and yield model for the mixed species forest of the Adirondacks region of New York, USA. For Ecosyst 3(26). https://doi.org/ 10.1186/s40663-016-0086-3

\footnotetext{
* Correspondence: christian.kuehne@maine.edu

The original article can be found online at https://doi.org/10.1186/s40663016-0086-3

'University of Maine, School of Forest Resources, Orono, ME 04469, USA

${ }^{4}$ University of Maine, 5755 Nutting Hall, Orono, ME 04469-5755, USA

Full list of author information is available at the end of the article
} 